\title{
Structuur van de palliatieve zorg in Vlaanderen.
}

Dr. Y. Lievens ${ }^{1,2}$, Dr. J. Menten ${ }^{1}$, I. Bossuyt ${ }^{1}$, M. Depril ${ }^{1}$.

\author{
${ }^{1}$ Palliatief-supportteam \\ Dienst Gezwelziekten \\ Universitaire Ziekenhuizen K.U.Leuven \\ ${ }^{2}$ Correspondentieadres \\ Dr. Y. Lievens \\ Dienst Gezwelziekten K.U.Leuven \\ Herestraat 49 \\ 3000 LEUVEN \\ yolande.lievens@uz.kuleuven.ac.be
}




\section{Samenvatting.}

Goede palliatieve opvang van de individuele patiënt veronderstelt een hechte samenwerking van de verschillende palliatieve hulpverleners. In de hierna volgende tekst wordt kort de palliatieve zorgstructuur in de Belgische context geschetst.

\section{Inleiding.}

Bijgaande figuur geeft een overzicht van de organisatiestructuur van de palliatieve zorg in België. Zij steunt op drie belangrijke pijlers:

- de thuiszorg, het eerste echelon van de palliatieve zorg,

- de palliatieve functies of palliatief-supportteams die actief zijn binnen de acute ziekenhuizen en de rust-en verzorgingstehuizen (RVT's),

- en tenslotte de palliatieve eenheden.

Op al deze niveaus zijn vrijwilligers-initiatieven actief. Overkoepelend vinden we de palliatieve netwerken terug.

\section{De verschillende actoren.}

\section{De palliatieve netwerken.}

De Interministeriële Conferentie van 7 mei 1996 was de eerste aanzet tot de erkenning van de regionale samenwerkingsverbanden, de zogenaamde palliatieve netwerken. Er is ongeveer 1 netwerk per 300000 inwoners, wat maakt dat er een dertigtal van deze netwerken geografisch verspreid in België voorkomen. Vlaanderen beschikt over 15 dergelijke netwerken. De wettelijke erkenning van deze netwerken was een verwezenlijking van de Vlaamse overheid.

$\mathrm{Zij}$ werken overkoepelend enerzijds voor de multidisciplinaire thuiszorgteams, anderzijds voor de intramurale palliatieve support-teams.

De bedoeling van deze netwerken is de samenwerking tussen de intra- en extramurale zorgverlener rond de palliatieve zorgbehoevende patiënt te bevorderen, alsook het ontwikkelen van een palliatieve zorgcultuur in een regio door sensibilisatie en organisatie van educatie.

In de palliatieve sector legt de Vlaamse overheid immers, naast kennisoverdracht en het aanleren van palliatieve attitudes, vooral de nadruk op interdisciplinaire samenwerking. Daartoe vergoedt ze per netwerk forfaitair 1 coördinator. Er worden geen vergoedingen voorzien per prestatie of per patiënt.

De federale overheid vertrekt vanuit het principe dat palliatie niet gezien dient te worden als een nieuw specialisme, doch eerder als een deskundigheid die deel uitmaakt van het dagelijks medisch en verpleegkundig handelen. Als dusdanig is palliatieve zorg dan ook niet het monopolie van 1 discipline, maar vereist ze van degenen die in contact komen met palliatieve zorg behoevende patiënten een "deskundige, interdisciplinaire, menselijke en niet louter technische omgang als hulpverlener met de patiënt en de familie". De federale overheid is derhalve geen voorstander van aparte diensten of palliatieve eenheden, maar steunt wel de idee van palliatieve equipes, zowel intra-als extramuraal.

\section{De thuiszorg.}

In de thuiszorg zijn er palliatieve thuiszorgequipes. Hierin werken palliatieve verpleegkundigen onder leiding van een palliatief coördinator. Hun taak is de professionele thuiszorgverleners binnen de regio, huisartsen en thuisverpleegkundigen, te ondersteunen en 
de palliatieve cultuur binnen dit gebied te verspreiden. Zij doen dus zelf niet aan actieve patiëntenzorg.

\section{De vrijwilligersinitiatieven.}

Het streefdoel van het Ministerie van Welzijn is dat er één vrijwilligersorganisatie in nauwe samenwerking met de palliatieve netwerken zou zijn, met name één per 300000 à 350000 inwoners. Ook op alle andere echelons werken er diverse vrijwilligersinitiatieven, zowel intraen extramuraal, waar zij een ondersteunende functie vervullen.

De grondslag van de wettelijke structuur waarin de andere palliatieve medespelers functioneren, werd gelegd op 15 juli 1997 met de formulering van een aantal Koninlijke Besluiten. Deze besluiten handelen over de bijzondere erkenning van de RVT's, over de architectonische normen van palliatieve eenheden binnen de acute ziekenhuizen en over de organisatie van de palliatieve supportteams.

\section{De palliatief-supportteams in de rust- en verzorgingstehuizen (RVT's).}

Het eerste van hoger vernoemde Koninklijke Besluiten betreft de normen voor de bijzondere erkenning van RVT's, waartoe een zesde punt definiëerd werd betreffende palliatieve zorg. Ter ondersteuning van de terminale zorgbehoevenden in een RVT zijn de geneesheer en hoofdverpleegkundige belast met het invoeren van een palliatieve zorgcultuur en de sensibilisering van het personeel, het formuleren van adviezen inzake palliatieve zorg, het bijwerken van de kennis van het medisch, verpleegkundig en paramedisch verzorgend personeel tewerkgesteld in een RVT. Verder moeten RVT's een functionele binding hebben met een Sp-dienst voor palliatieve verzorging en meewerken aan het samenwerkingsverband inzake palliatieve zorg dat het desbetreffend geografisch gebied bestrijkt. Gezien er echter geen financieringen werden voorzien om dit te realiseren zijn vele van deze palliatieve functies nog vaak onvoldoende operationeel.

\section{De palliatieve functies in de acute ziekenhuizen.}

De ziekenhuisfuncties van palliatieve zorg, ook wel palliatief-supportteams genoemd, zijn gevormd door een pluridisciplinair team, komende uit het medisch, het verpleegkundig en het paramedisch departement van het ziekenhuis, die een specifieke opleiding in de palliatieve zorg gevolgd hebben. Verder moet het team beroep kunnen doen op een psycholoog, een maatschappelijk assistent of een sociaal verpleegkundige.

Het palliatief-supportteam is niet rechtstreeks bij de eigenlijke behandeling en verzorging betrokken, doch is verantwoordelijk voor alle activiteiten die de behandeling en de opvang van de palliatieve en terminale ziekenhuispatiënten ondersteunen, met name:

- de palliatieve zorgcultuur invoeren en het gezamenlijk ziekenhuispersoneel bewust maken van de noodzaak hiervan;

- advies geven inzake palliatieve zorg aan de geneesheren, de verpleegkundigen en de paramedici van het ziekenhuis, alsook de ziekenhuisdirectie adviseren over het terzake te voeren beleid;

- zorgen voor de permanente opleiding van het ziekenhuispersoneel in palliatieve zorg;

- zorgen voor continuïteit van de palliatieve zorgverlening binnen het ziekenhuis alsook transmuraal wanneer de patiënt het ziekenhuis verlaat om naar huis te gaan of in een RVT te worden opgenomen.

Om erkend te worden en te blijven, dienen dergelijke supportteams een functionele binding te hebben met een $\mathrm{Sp}$-dienst voor palliatieve zorg (= palliatieve eenheid) en ook mee te werken 
aan het regionale samenwerkingsverband en met de organisatie van thuiszorg van het desbetreffende geografische gebied.

\section{De palliatieve eenheden.}

Een palliatieve eenheid of Sp-dienst voor palliatieve verzorging is bestemd voor patiënten met een ongeneeslijke ziekte die in de terminale fase palliatieve zorg nodig hebben en die omwille van te beperkte mantelzorg of om andere redenen niet (meer) in de thuissituatie verzorgd kunnen worden. Men legt er zich specifiek toe op pijn- en symptoomcontrole, psychosociale en spirituele begeleiding, rouwvoorbereiding en -begeleiding.

De bedden van dergelijke dienst vormen bij voorkeur een architectonisch zelfstandige en herkenbare entiteit. Dergelijke diensten bevatten 6 à 12 bedden en verder zijn er een aantal specifieke vereisten wat betreft ruimte, sanitair, meubilair en gemeenschappelijke ruimten. De noodzakelijke technische middelen voor pijnbestrijding dienen aanwezig te zijn. Voor de familieleden moet de mogelijkheid bestaan om de dienst 24 uur op 24 te bezoeken en tevens om op de dienst te overnachten.

Dergelijke dienst organiseert wekelijks interdisciplinaire teamvergaderingen en wordt geleid door een geneesheer-specialist met bijzondere ervaring in de palliatieve verzorging. Met inbegrip van de hoofdverpleegkundige dient de dienst per erkend bed over 1,25 verpleegkundige te beschikken, bijgestaan door voldoende verzorgend personeel. De dienst moet beroep kunnen doen op geneesheer-specialisten in de oncologie, de anesthesiologie, de geriatrie en de psychiatrie, en verder ook op een kinesitherapeut, een maatschappelijk werker, een levensbeschouwelijk begeleider en een psycholoog.

De teamleden dienen voldoende opleiding in palliatieve zorg genoten te hebben en de permanente opleiding bedraagt minimum twee dagen per jaar per hulpverlener.

Naast deze palliatieve eenheden zijn er recent in België ook een aantal palliatieve dagverblijven opgestart, hun bedoeling is tijdens de dag de mantelzorg te ondersteunen.

\section{Besluit en toekomstperspectieven.}

De structurele organisatie van de palliatieve zorg in België werd in minder dan 5 jaar ontwikkeld dankzij de zeer sterke interactie tussen de actoren in het werkveld en de beleidvoerders. Zij mag beschouwd worden als een voorbeeld van organisatie binnen Europa. In de komende jaren zullen de financiële middelen progressief worden aangepast zodat vooral ook intramuraal de Koninklijke Besluiten gerealiseerd kunnen worden. 
Figuur 1: Organisatiestructuur van de palliatieve zorg in België.

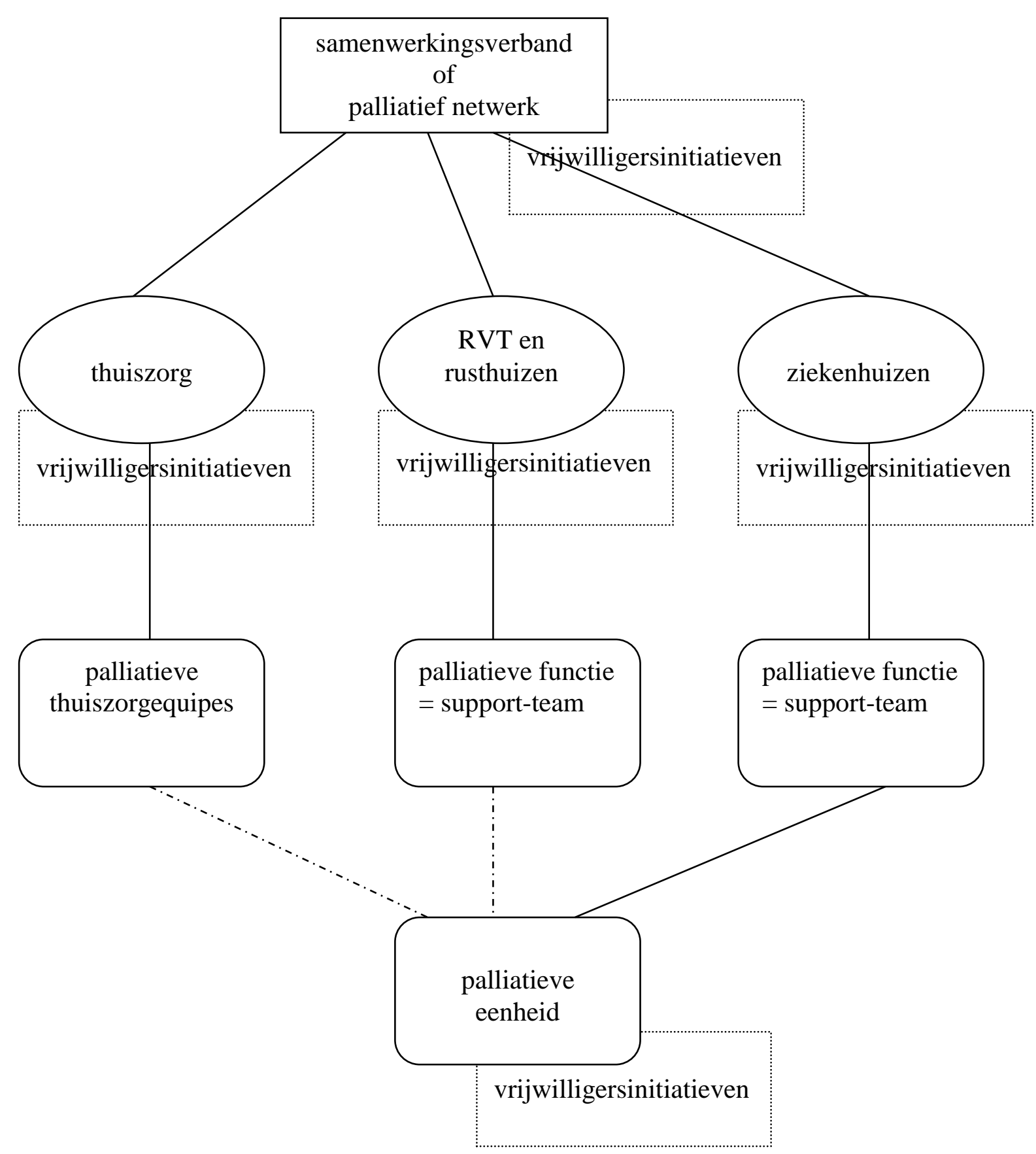

